\section{International Scientific Journal Theoretical \& Applied Science}

p-ISSN: $2308-4944$ (print)

e-ISSN: 2409-0085 (online)

Year: 2018

Issue: 01

Volume: 57

Published: $30.01 .2018 \quad$ http://T-Science.org
Gennady Evgenievich Markelov

Candidate of Engineering Sciences, associate professor, corresponding member of International Academy of Theoretical and Applied Sciences, Bauman Moscow State Technical University,

Moscow, Russia markelov@bmstu.ru

SECTION 2. Applied mathematics. Mathematical modeling.

\title{
MATHEMATICAL MODEL OF A TECHNICAL SYSTEM ELEMENT
}

Abstract: A mathematical model of a technical system element was obtained using a unified approach to building a working mathematical model. The technical system element includes a resistor with temperaturedependent conductivity and total heat capacity. The constructed model possesses sufficient fullness, accuracy, adequacy, productivity and economy. Applying such a mathematical model reduces the costs and time spent on research and makes efficient use of the mathematical modeling capabilities.

Key words: working mathematical model, properties of mathematical models, principles of mathematical modeling.

Language: English

Citation: Markelov GE (2018) MATHEMATICAL MODEL OF A TECHNICAL SYSTEM ELEMENT. ISJ Theoretical \& Applied Science, 01 (57): 111-113.

Soi: http://s-o-i.org/1.1/TAS-01-57-20 Doi: crossef https://dx.doi.org/10.15863/TAS.2018.01.57.20

\section{Introduction}

Approaches to building mathematical models of various technical systems are described in numerous educational and scientific literature. Articles [1; 2] introduce the concept of a working mathematical model and describe a unified approach to building a mathematical model that has the desired properties to a degree sufficient for a particular study. Some properties of mathematical models are described in [3; 4]. Article [5] contains an example of building a mathematical model that has the required properties to a degree sufficient for a particular study. Some of the results of this study are presented in [6-8]. The specifics of implementing a unified approach to building mathematical models are discussed in [9; 10].

The aim of this study is to build a working mathematical model of a technical system element using a unified approach. The technical system element includes a resistor with temperaturedependent conductivity and total heat capacity.

\section{Statement of the problem}

The resistor shall be considered a body with high thermal conductivity, the temperature $T$ of which at the initial time point $t_{0}$ is equal to $T_{0}$. The resistor has the surface area $S$ where convective heat exchange with the environment occurs, the ambient temperature is equal to $T_{0}$; the heat transfer coefficient is known and equal to $\alpha$. Let

$$
\begin{aligned}
& G(T)=G_{0}\left[1+\beta\left(T-T_{0}\right)\right], \\
& C(T)=C_{0}\left[1+\gamma\left(T-T_{0}\right)\right],
\end{aligned}
$$

where $G(T)$ and $C(T)$ are the conductivity and total heat capacity of the resistor; $G_{0}$ and $C_{0}$ are the conductivity and total heat capacity of the resistor when $T=T_{0} ; \beta$ and $\gamma$ are the temperature coefficients, with $\beta>0$ and $\gamma>0$. The difference of electric potentials at the poles of the element in question is equal to

$$
U=\frac{I}{G_{0}\left[1+\beta\left(T-T_{0}\right)\right]},
$$

where $I$ is the direct current flowing through the resistor.

Let us assume that the value $U$ is of interest in this study. Let us build a working mathematical model of the object of the study which possesses sufficient fullness, accuracy, adequacy, productivity and economy.

\section{Solution}

To solve this problem, we will construct a hierarchy of mathematical models of the object of the study and determine the conditions under which we can calculate the sought value $U$ with a relative error of no more than the specified value $\delta_{0}$. 


\begin{tabular}{|c|c|c|c|c|c|c|}
\hline Impact Factor: & $\begin{array}{l}\text { ISRA (India) } \\
\text { ISI (Dubai, UAF } \\
\text { GIF (Australia) } \\
\text { JIF }\end{array}$ & $\begin{array}{l}=1.344 \\
=0.829 \\
=0.564 \\
=1.500\end{array}$ & $\begin{array}{l}\text { SIS (USA) } \\
\text { PИНЦ (Russia } \\
\text { ESJI (KZ) } \\
\text { SJIF (Morocce }\end{array}$ & $\begin{array}{l}=0.912 \\
=0.207 \\
=4.102 \\
=\mathbf{2 . 0 3 1}\end{array}$ & $\begin{array}{l}\text { ICV (Poland) } \\
\text { PIF (India) } \\
\text { IBI (India) }\end{array}$ & $\begin{array}{l}=6.630 \\
=1.940 \\
=4.260\end{array}$ \\
\hline
\end{tabular}

If the difference $T-T_{0}$ is sufficiently small, then according to (1) the sought value can be calculated using the following formula:

$$
U_{0}=I / G_{0} \text {. }
$$

Let us define the conditions under which the resulting formula is applicable. To do this, let us consider steady-state heat transfer. In this case, the heat output of the resistor's material is equal to the heat flow from the resistor, that is,

$$
\frac{I^{2}}{G_{0}\left[1+\beta\left(T_{*}-T_{0}\right)\right]}=\alpha\left(T_{*}-T_{0}\right) S,
$$

where $T_{*}$ is the steady-state resistor temperature. The resulting equality allows us to easily calculate

$$
T_{*}=T_{0}+\frac{1}{2 \beta}\left(-1+\sqrt{1+\frac{4 \beta I^{2}}{\alpha S G_{0}}}\right),
$$

and then find the steady-state value

$$
U_{*}=I / G\left(T_{*}\right)=\frac{2 U_{0}}{1+\sqrt{1+4 \beta I U_{0} /(\alpha S)}} .
$$

It is evident that $U_{*} \leq U \leq U_{0}$. Then the following is true for the relative error of $U_{0}$ :

$$
\delta\left(U_{0}\right)=\left|\frac{U-U_{0}}{U}\right|=\frac{U_{0}}{U}-1 \leq \frac{U_{0}}{U_{*}}-1 .
$$

Therefore, if the condition

$$
\frac{U_{0}}{U_{*}}-1 \leq \delta_{0}
$$

is met, formula (2) may be used to find the sought value with a relative error of no more than $\delta_{0}$. Then, we obtain the following inequality:

$$
\frac{\beta I^{2}}{\alpha S G_{0}} \leq \delta_{0}^{2}+\delta_{0} .
$$

When this inequality is satisfied, mathematical model (2) has sufficient fullness, accuracy, adequacy, productivity and economy.

Let us define the conditions under which mathematical model (3) is applicable. To do this, let us consider unsteady-state heat transfer. In this case, the change in the temperature of the resistor over time $t$ is described by the following first-order ordinary differential equation:

$$
C(T) \frac{d T}{d t}=\frac{I^{2}}{G(T)}-\alpha\left(T-T_{0}\right) S,
$$

and the initial condition is as follows:

$$
T\left(t_{0}\right)=T_{0} .
$$

Given that

$$
U=\frac{U_{0}}{1+\beta\left(T-T_{0}\right)},
$$

let us formulate a Cauchy problem:

$$
\begin{aligned}
& \frac{d U}{d t}=\frac{\beta U^{2}\left[\alpha S\left(U_{0}-U\right)-\beta I U^{2}\right]}{C_{0} U_{0}\left[\gamma\left(U_{0}-U\right)+\beta U\right]}, \\
& U\left(t_{0}\right)=U_{0} .
\end{aligned}
$$

If the condition

$$
\delta\left(U_{*}\right)=\left|\frac{U-U_{*}}{U}\right|=1-\frac{U_{*}}{U} \leq \delta_{0}
$$

is met, formula (3) may be used to find the sought value with a relative error of no more than $\delta_{0}$ when

$$
\delta_{0}<\frac{U_{0}}{U_{*}}-1,
$$

since otherwise formula (2) should be used. Then, let us find the time point

$$
\begin{aligned}
t_{*}= & t_{0}+\frac{C_{0}}{\alpha S}\left[\frac{\gamma}{\beta}\left(\frac{U_{*}}{U_{0}}-1+\delta_{0}\right) \frac{U_{0}}{U_{*}}+\left(\frac{U_{0}}{2 U_{0}-U_{*}}+\right.\right. \\
& \left.+\frac{\gamma}{\beta} \frac{U_{0}-U_{*}}{2 U_{0}-U_{*}} \frac{U_{0}}{U_{*}}-1\right) \ln \left(2-\frac{U_{*}}{U_{0}}-\delta_{0}\right)- \\
& \left.-\left(\frac{U_{0}}{2 U_{0}-U_{*}}+\frac{\gamma}{\beta} \frac{U_{0}-U_{*}}{2 U_{0}-U_{*}} \frac{U_{0}}{U_{*}}\right) \ln \left(\frac{U_{0}}{U_{0}-U_{*}} \delta_{0}\right)\right],
\end{aligned}
$$

for which the following is true:

$$
U\left(t_{*}\right)=U_{*} /\left(1-\delta_{0}\right) .
$$

Then, according to (5), the steady-state value $U_{*}$ can be regarded as equal to $U(t)$ when $t \geq t_{*}$ with a relative error of no more than $\delta_{0}$.

If condition (4) is not met, mathematical model (3) possesses sufficient fullness, accuracy, adequacy, productivity and economy when $t \geq t_{*}$.

Building a new mathematical model when creating a hierarchy of mathematical models for the object of the study may lead to refining the previously determined conditions for the applicability of the constructed mathematical models. Indeed, using mathematical model (5), we can refine the condition of applicability for formula (2). For this let us calculate the time point

$$
\begin{aligned}
& t^{*}=t_{0}+\frac{C_{0}}{\alpha S}\left[\left(\frac{U_{0}}{2 U_{0}-U_{*}}+\right.\right. \\
&\left.+\frac{\gamma}{\beta} \frac{U_{0}-U_{*}}{2 U_{0}-U_{*}} \frac{U_{0}}{U_{*}}-1\right) \ln \left(1+\frac{U_{*}}{U_{0}} \delta_{0}\right)-\frac{\gamma}{\beta} \delta_{0}- \\
&\left.-\left(\frac{U_{0}}{2 U_{0}-U_{*}}+\frac{\gamma}{\beta} \frac{U_{0}-U_{*}}{2 U_{0}-U_{*}} \frac{U_{0}}{U_{*}}\right) \ln \left(1-\frac{U_{*} \delta_{0}}{U_{0}-U_{*}}\right)\right]
\end{aligned}
$$

for which the following is true:

$$
U\left(t^{*}\right)=U_{0} /\left(1+\delta_{0}\right) .
$$

Then, $U_{0}$ can be regarded as equal to $U(t)$ when $t \leq t^{*}$ with a relative error of no more than $\delta_{0}$.

If condition (4) is met or $t \leq t^{*}$, mathematical model (2) possesses sufficient fullness, accuracy, adequacy, productivity and economy.

\section{Results}

By constructing a hierarchy of mathematical models, we can identify a working mathematical 


\begin{tabular}{|c|c|c|c|c|c|c|}
\hline Impact Factor: & $\begin{array}{l}\text { ISRA (India) } \\
\text { ISI (Dubai, UAE } \\
\text { GIF (Australia) } \\
\text { JIF }\end{array}$ & $\begin{array}{l}=1.344 \\
=0.829 \\
=0.564 \\
=1.500\end{array}$ & $\begin{array}{l}\text { SIS (USA) } \\
\text { PИНЦ (Russia) } \\
\text { ESJI (KZ) } \\
\text { SJIF (Morocco) }\end{array}$ & $\begin{array}{l}=0.912 \\
=0.207 \\
=4.102 \\
=\mathbf{2 . 0 3 1}\end{array}$ & $\begin{array}{l}\text { ICV (Poland) } \\
\text { PIF (India) } \\
\text { IBI (India) }\end{array}$ & $\begin{array}{l}=6.630 \\
=1.940 \\
=4.260\end{array}$ \\
\hline
\end{tabular}

model that possesses the desired properties to a degree sufficient for a specific study. Indeed, if inequality (4) is satisfied, or $t \leq t^{*}$ in the scope of the conducted study, then (2) is considered the working mathematical model. If condition (4) is not met, and the time interval from $t_{0}$ to $t_{*}$ may be disregarded in the conducted study, (3) will be chosen as the working mathematical model, otherwise (5) will be the working mathematical model.

\section{Conclusion}

Thus, a unified approach was used to formulate the statements that allow us to define a mathematical model of a technical system element. The constructed mathematical model possesses sufficient fullness, accuracy, adequacy, productivity and economy.

It is evident that the use of such a model reduces the costs and time spent on research and makes efficient use of the mathematical modeling capabilities.

\section{References:}

1. Markelov GE (2015) On Approach to Constructing a Working Mathematical Model. ISJ Theoretical \& Applied Science, 04 (24): 287-290. Soi: http://s-oi.org/1.1/TAS*04(24)52 Doi: http://dx.doi.org/10.15863/TAS.2015.04.24.52

2. Markelov GE (2015) Constructing a Working Mathematical Model. ISJ Theoretical \& Applied Science, 08 (28): 44-46. Soi: http://s-oi.org/1.1/TAS-08-28-6 Doi: http://dx.doi.org/10.15863/TAS.2015.08.28.6

3. Myshkis AD (2011) Elements of the Theory of Mathematical Models [in Russian]. URSS, Moscow.

4. Zarubin VS (2010) Mathematical Modeling in Engineering [in Russian]. Izd-vo MGTU im. N.E. Baumana, Moscow.

5. Markelov GE (2012) Peculiarities of Construction of Mathematical Models. Inzhenernyi zhurnal: nauka i innovatsii, No. 4, Available:

http://engjournal.ru/catalog/mathmodel/hidden/ 150.html (Accessed: 15.01.2018).

6. Markelov GE (2000) Effect of initial heating of the jet-forming layer of shaped-charge liners on the ultimate elongation of jet elements. J. Appl. Mech. and Tech. Phys., 41, No. 2, pp. 231-234.

7. Markelov GE (2000) Effect of initial heating of shaped charge liners on shaped charge penetration. J. Appl. Mech. and Tech. Phys., 41, No. 5, pp. 788-791.

8. Markelov GE (2000) Influence of heating temperature on the ultimate elongation of shaped-charge jet elements. Proc. of the 5th Int. Conf. "Lavrentyev Readings on Mathematics, Mechanics and Physics", Lavrentyev Institute of Hydrodynamics, Novosibirsk, p. 170.

9. Markelov GE (2015) Particular Aspects of Teaching the Fundamentals of Mathematical Modeling. ISJ Theoretical \& Applied Science, 05 (25): 69-72. Soi: http://s-oi.org/1.1/TAS*05(25)14 Doi: http://dx.doi.org/10.15863/TAS.2015.05.25.14

10. Markelov GE (2016) Teaching the Basics of Mathematical Modeling. Part 2. ISJ Theoretical \& Applied Science, 01 (33): 72-74. Soi: http://s-o-i.org/1.1/TAS-01-33-15 Doi: http://dx.doi.org/10.15863/TAS.2016.01.33.15 